University of Nebraska - Lincoln

DigitalCommons@University of Nebraska - Lincoln

Faculty Papers and Publications in Animal

Science

Animal Science Department

1975

\title{
Influence of Exercise on Performance and Carcass Parameters of Confinement Reared Swine
}

\author{
G. M. Weiss \\ Win Butler University \\ E. R. Peo, Jr. \\ University of Nebraska-Lincoln \\ R. W. Mandingo \\ University of Nebraska-Lincoln \\ B. D. Moser \\ University of Nebraska-Lincoln
}

Follow this and additional works at: https://digitalcommons.unl.edu/animalscifacpub

Part of the Animal Sciences Commons

Weiss, G. M.; Peo, Jr., E. R.; Mandingo, R. W.; and Moser, B. D., "Influence of Exercise on Performance and Carcass Parameters of Confinement Reared Swine" (1975). Faculty Papers and Publications in Animal Science. 642.

https://digitalcommons.unl.edu/animalscifacpub/642

This Article is brought to you for free and open access by the Animal Science Department at DigitalCommons@University of Nebraska - Lincoln. It has been accepted for inclusion in Faculty Papers and Publications in Animal Science by an authorized administrator of DigitalCommons@University of Nebraska - Lincoln. 


\title{
INFLUENCE OF EXERCISE ON PERFORMANCE AND CARCASS PARAMETERS OF CONFINEMENT REARED SWINE ${ }^{1}$
}

\author{
G. M. Weiss ${ }^{2}$, E. R. Peo, Jr., R. W. Mandigo and B. D. Moser ${ }^{3}$ \\ Nebraska Agricultural Experiment Station, Lincoln 68503
}

\begin{abstract}
Summary
Fifty-six crossbred growing and finishing swine were used to determine the effect of treadmill exercise on several performance and carcass parameters when housed in confinement on $100 \%$ slatted floors. The exercised swine were subjected to walking $1.6 \mathrm{~km} / \mathrm{hr}$ for $1 \mathrm{hr} 5$ days per week. The mean experimental duration was 71 days. Jugular vein blood samples and gracilus muscle biopsy samples were obtained prior and following completion of exercise. Exercise had no major influence on average daily gain, daily feed intake or gain/feed ratio. Bone breaking strength of the left fourth metatarsal was significantly $(\mathrm{P}<.01)$ greater for exercised pigs than non exercised. However, right third and fourth metatarsal and left third metatarsal bone breaking strengths were not influenced by exercise. Similarly exercise did not affect longissimus muscle color or marbling scores, myoglobin concentration, water holding capacity, penetrometer or shear values, proximate analysis or cooking loss. Growth and advance in maturity resulted or were associated with a significant $(P<.05)$ decline in serum glucose, $(\mathrm{P}<.01)$ lactate concentration, and $(\mathrm{P}<.01)$

\footnotetext{
${ }^{1}$ Published with approval of the Director as Paper Number 3706. Journal Series, Nebraska Agricultural Experiment Station. Research reported was conducted under Project Number 13-23.

${ }^{2}$ Present address, Box 117, Cottage Grove, Wisconsin 53527.

${ }^{3}$ The authors wish to express their gratitude to $\mathrm{Mr}$. Thomas Socha for his assistance with the statistical analysis, and to Mr. Tim Stahly for his laboratory assistance.
}

blood cholesterol concentrations. Exercise had no influence on glucose, lactate, blood cholesterol or liver cholesterol. A significant $(P<.01)$ increase in sarcoplasmic and myofibrillar protein was found as a result of growth, but exercise had no influence on protein extractability. Exercise did not significantly affect RNA-DNA ratio.

\section{Introduction}

Confinement rearing of swine encompasses various facility and management conditions and when combined with high pig density, in tensified selection for performance and carcass meatiness has resulted in new challenges to the swine population.

Svajgr et al. $(1968,1969)$ observed that pigs on pasture appeared to have fewer leg problems and stronger bones than those reared on solid or slatted concrete floors. The influence of exercise on bone strength and physiological development is not well defined. This investigation was designed to determine the effect of 60 min of treadmill exercise 5 days per week on live animal performance and various carcass parameters.

\section{Materials and Methods}

Five trials involving 12 crossbred growing and finishing swine per trial were housed individually on slatted floor pens in an environmentally controlled experimental facility at the University of Nebraska. Fifty-six swine were involved in the study, four pigs were eliminated as a result of inability to adjust to exercise conditions. The swine were provided 
with automatic waterers and were self fed a $14 \%$ corn-milo-soybean meal diet. Daily gain, feed intake and feed conversion were determined on an individual pig basis.

At the initiation of each experiment the swine were randomly allotted to treadmill exercise or the control treatment. Treadmill exercise involved walking on a continuous belt for $60 \mathrm{~min} /$ day at the rate of $1.6 \mathrm{~km} / \mathrm{hr} 5$ days per week. The swine were on test for an average of 71 days of exercise.

Each pig was bled via jugular puncture to obtain blood for cholesterol determinations by the procedure of (Pearson et al., 1953). Initial serum lactate was determined by the procedure of Marbach and Weil (1967) and glucose by the method of Raabo and Terkildsen (1960) on 12 exercised and 11 control swine. A biopsy of the left gracilus muscle (Moser et al., 1972) was also obtained for RNA-DNA analysis (Schnieder, 1945) at initiation of two of the five trials. A portion of the muscle biopsy was used for sarcoplasmic and myofibrillar protein extraction and NPN content with a modified procedure of Helendar (1957) and Lawrie (1961) as described by Topel and Merkel (1967). Total nitrogen content was determined by Kjeldahl analysis (A.O.A.C., 1965). In addition, a portion of the right gracilus was removed for RNA-DNA analysis and protein extractability $12 \mathrm{~min}$ following exsanguination on the swine biopsied prior to initiation of the respective two trials. Twenty-five minutes post exsanguination a liver sample was obtained in four of the five trials for liver cholesterol analysis (Stromer et al., 1966). Blood samples were taken by jugular puncture and provided complementary cholesterol, lactate and glucose data.

Carcass measurements included length and backfat (A.M.S.A., 1967); and subjective muscle score (U.S.D.A., 1969). Following a 24-hr chill at $2 \mathrm{C}$ the carcasses were separated into wholesale cuts and percent ham, ham and loin, lean cuts and primal cuts were determined (A.M.S.A., 1967). Area of the longissimus muscle was determined on the cross section loin at the 9th and 10th rib (A.M.S.A., 1967).

Marbling score and longissimus muscle color score were subjectively determined (Annonymous, 1963) on the cross sectioned loins at the 9 th and 10th rib. Two $2.54 \mathrm{~cm}$ thick pork chops were obtained at the cross sectioned location for chemical and physical analyses. Proximate analyses were conducted according to methods described in A.O.A.C., 1965. Myoglobin concentration was determined by the procedure adapted by Topel (1966). Firmness was measured to the nearest $.01 \mathrm{~mm}$ by use of a penetrometer equipped with a 19 $\mathrm{mm}$ round stainless steel ball; measurements were taken at the proximal and distal positions on the cut surface of the longissimus muscle. Water holding capacity determinations were carried out by methods described by Wierbicki et al. (1957). One pork chop from each carcass was weighed and then cooked at $177 \mathrm{C}$ in an electric rotary hearth oven to an internal temperature of $70 \mathrm{C}$. The chop was blotted dry and reweighed to determine cooking loss. Warner-Bratzler shear values were obtained on proximal and distal $2.54 \mathrm{~cm}$ diameter cores removed from the cooked samples.

The hams were processed according to conventional procedures used in the industry. Following a 24-hr chill at $2 \mathrm{C}$ each ham was separated into shank, butt and center portions and acetate tracings were made of the lean, fat and bone. Percentage tissue area was then determined for each cross-section.

The right and left rear legs were removed below the hock to obtain the third and fourth metatarsal bones for bone breaking strength (BKS) determinations. Preparation of the bones and determination of BKS were according to the method of Svajgr et al. (1969).

The data were analyzed using analysis of variance procedures appropriate for data with unequal subclass numbers (Harvey, 1960). Final weight was included as a covariable in the analysis of variance for BKS, carcass measurements and chemical determinations (Steel and Torrie, 1960). The covariable was used to adjust all means to the same off-test weight.

\section{Results and Discussion}

The effect of minimal exercise associated with confinement rearing of swine has only recently been the subject of scientific investigation. Peo et al. (1970) conducted a study involving six barrows and six gilts and three time durations of treadmill exercise, varying from $15 \mathrm{~min}$ to 1 hour. They found no influence of treadmill exercise for $1 \mathrm{hr}$ on average daily gain or feed conversion. Mandigo 
TABLE 1. LEAST SQUARES MEANS AND STANDARD ERRORS FOR PERFORMANCE

TRAITS AND BONE BREAKING STRENGTH

\begin{tabular}{|c|c|c|c|c|c|c|}
\hline Source & No. & & Non-exercise & & $x^{x e r c i s e} b^{b}$ & $\begin{array}{c}\text { Coefficient } \\
\text { of } \\
\text { variation }\end{array}$ \\
\hline Avg daily gain ${ }^{2} \mathrm{~kg}$ & 56 & .89 & $\pm \quad .014$ & .85 & $\pm \quad .013$ & - \\
\hline Avg daily feed intakea $\mathrm{kg}$ & 56 & 3.13 & .07 & 3.04 & .07 & - \\
\hline Gain/feed ratio ${ }^{a}$ & 56 & .29 & .01 & .28 & .01 & - \\
\hline $\begin{array}{l}\text { Right third metatarsala } \mathrm{kg} \\
\text { force }\end{array}$ & & & & & & \\
\hline $\begin{array}{l}\text { force } \\
\text { Right fourth metatarsala } \mathrm{kg}\end{array}$ & 56 & 236 & \pm 10 & 262 & \pm 9 & 39 \\
\hline $\begin{array}{l}\text { force } \\
\text { Left third metatarsala } \mathrm{kg}\end{array}$ & 56 & 200 & \pm 10 & 224 & \pm 10 & 39 \\
\hline $\begin{array}{l}\text { force } \\
\text { Left fourth metatarsala } \mathrm{kg}\end{array}$ & 56 & 239 & \pm 12 & 252 & \pm 11 & 40 \\
\hline $\begin{array}{l}\text { force } \\
\text { Avg bone breaking strengtha }\end{array}$ & 56 & $192 * *$ & \pm 11 & $239 * *$ & \pm 11 & 39 \\
\hline $\mathrm{kg}$ force & 112 & 217 & \pm 11 & 244 & \pm 10 & 39 \\
\hline
\end{tabular}

asignificant $P<.01$ trial difference.

bSixty-minute treadmill exercise 5 days/week.

* Significant $\mathbf{p}<.01$.

et al. (1971) reported no influence of treadmill exercise on average daily gain or feed consumption of growing and finishing swine. They did find a significantly $(P<.05)$ greater gain per pound of feed for the exercised pigs. Data in table 1 indicate no significant $(P<.05)$ influence of exercise on performance traits for the swine used in this study.

Exercised swine possessed significantly $(\mathrm{P}<.01)$ greater left fourth metatarsal BKS than non-exercised pigs table 1 . No major differences were found for right and left third metatarsal or right fourth metatarsal BKS. Irrespective of the associated coefficients of variation, the general tendency for exercised pigs was to exhibit greater BKS than nonexercised pigs.

The results shown in table 1 are in direct contrast to those of Peo et al. (1970) in which non-exercised pigs possessed greater BKS. Svajgr et al. (1968) and Svajgr et al. (1969) reported greater BKS in swine raised on pasture than from those raised in confinement.

Svajgr et al. (1968) reported no difference for backfat, longissimus area, percent ham and loin, or carcass length on pigs reared in confinement vs dry lot with an exercise area. Peo et al. (1970) reported that treadmill exercise altered significantly the percent lean cuts but none of the other measured carcass traits. Mandigo et al. (1971) indicated no significant $(P<.05)$ influence of exercise on percent lean cuts, primal cuts, ham and loin, ham or longissimus area. Significantly $(P<.05)$ greater backfat was found for exercised pigs. Data in table 2 shows no major influence of exercise on length, backfat, muscle score, respective percent wholesale cuts or longissimus area. Significant differences in carcass measurements were noted among trials.

\section{TABLE 2. LEAST SQUARES MEANS AND STANDARD ERRORS FOR CARCASS MEASUREMENTS}

\begin{tabular}{|c|c|c|c|}
\hline Source & No. & Non-exercise & Exercisec \\
\hline Lengthb cm & 56 & $76.60 \pm .37$ & $76.57 \pm .36$ \\
\hline Backfat $^{a} \mathrm{~cm}$ & 56 & $3.72 \pm .08$ & $3.63 \pm .08$ \\
\hline Muscle score & 56 & $3.04 \pm .13$ & $3.26 \pm .13$ \\
\hline \% hamb & 56 & $20.13 \pm .29$ & $20.40 \pm .28$ \\
\hline$\%$ ham and & 56 & $37.62 \pm .38$ & $37.85 \pm .37$ \\
\hline $\begin{array}{l}\% \text { lean cutsa } \\
\% \text { primal }\end{array}$ & 56 & $55.06 \pm .50$ & $55.47 \pm .48$ \\
\hline cuts $a$ & 56 & $69.37 \pm .40$ & $69.73 \pm .38$ \\
\hline $\begin{array}{l}\text { Loin eye } \\
\text { areab } \mathrm{cm}^{2}\end{array}$ & 56 & $28.51 \pm .58$ & $29.02 \pm .58$ \\
\hline
\end{tabular}

aSignificant $P<.01$ trial difference.

b Significant $P<.05$ trial difference.

c Sixty minute treadmill exercise 5 days/week. 
TABLE 3. LEAST SQUARES MEANS AND STANDARD ERRORS FOR CARCASS QUALITATIVE, CHEMICAL AND PHYSICAL MEASUREMENTS

\begin{tabular}{llrr}
\hline \hline Source & No. & Non-exercise & Exercisec $^{\mathrm{c}}$ \\
\hline Longissimus muscle colora & 56 & $2.53 \pm .13$ & $2.49 \pm .12$ \\
Longissimus muscle marbling & 56 & $2.68 \pm .22$ & $2.48 \pm .22$ \\
Myoglobin mg/g & 56 & $.428 \pm .047$ & $.444 \pm .045$ \\
Water-holding capacity $\mathrm{a}$ ml of juice & 56 & $6.19 \pm .15$ & $6.28 \pm .14$ \\
Penetrometerb mm & 56 & $4.65 \pm .22$ & $4.57 \pm .21$ \\
Warner-Bratzler sheara & 56 & $14.22 \pm .53$ & $13.90 \pm .51$ \\
Moisture \%a & 56 & $71.22 \pm .23$ & $71.42 \pm .22$ \\
Ether extract \%a & 56 & $5.00 \pm .34$ & $4.58 \pm .33$ \\
Protein \% & 56 & $21.96 \pm .18$ & $21.85 \pm .17$ \\
Ash \% & 44 & $1.12 \pm .02$ & $1.11 \pm .03$ \\
Cooking loss \%a & 56 & $21.35 \pm .50$ & $21.98 \pm .49$ \\
\hline
\end{tabular}

a Significant $P<.01$ trial difference.

bSignificant $P<.05$ trial difference.

cSixty-minute treadmill exercise 5 days/week.

No major influence of treadmill exercise was found for the various carcass qualitative, chemical or physical measurements (table 3 ). This agrees with the earlier report of Mandigo et al. (1971) in which treadmill exercised swine were not significantly different $(\mathrm{P}<.05)$ from non-exercised swine for marbling score, longissimus muscle color, cooking loss, firmness, shear force values, proximate analysis, myoglobin concentration or water holding capacity. A significant trial difference for the various measurements again indicating the variability between experimental groups (table 3).

The physiological impact of exercise has been studied extensively in man, mice and rats. Analysis of serum glucose and lactate as well as blood cholesterol were studied to evaluate energy metabolism. Serum glucose decreased significantly $(\mathrm{P}<.05)$ during the course of the study (table 4). This would appear to be the result of physiological changes manifested during growth (Weiss et al.,1971). No influence of exercise was observed upon glucose concentration. Weiss et al. (1974) reported increased circulatory glucose levels as the result of severe short term exercise of swine. This was more likely the result of an induced stressed status rather than a conditioned exercise response as shown in table 4.

Serum lactate data in table 4 show a significant $(\mathrm{P}<.01)$ concentration decline from the first bleeding to the second. In a growth and development study involving swine (Weiss et al., 1971) indicated no influence of growth on serum lactate. Physical exercise greatly influences blood lactate and the degree of exercise must be considered in the discussion of

TABLE 4. LEAST SQUARES MEANS AND STANDARD ERRORS FOR SEVERAL PHYSIOLOGICAL PARAMETERS

\begin{tabular}{|c|c|c|c|}
\hline Source & No. & Non-exercise & Exercise $b$ \\
\hline Serum glucose I mg\% & 23 & $113.70^{*} \pm 4.20$ & $110.38 *$ \\
\hline Serum glucose II mg\% & 23 & $101.54^{*} \pm 9.90$ & $97.42 * \pm 9.44$ \\
\hline Serum lactate I mg\% & 23 & $66.07 * * \pm 8.97$ & $81.88 * * \pm 8.56$ \\
\hline Serum lactate II mg\% & 23 & $48.98 * * \pm 10.36$ & $52.60 * * \pm 9.88$ \\
\hline Blood cholesterol Ia mg\% & 56 & $172 * * \pm 6$ & $163 * * \pm 6$ \\
\hline Blood cholesterol IIa mg\% & 46 & $136 * *$ & $129 * *$ \\
\hline Liver cholesterol mg/g & 45 & $\pm \quad .09$ & \pm .09 \\
\hline
\end{tabular}

asignificant $P<.01$ trial difference.

b Sixty-minute treadmill exercise 5 days/week.

$* *$ Significant $\mathrm{P}<.01$.

* Significant $\mathrm{P}<.05$. 
TABLE 5. LEAST SQUARES MEANS AND STANDARD ERRORS FOR GRACILUS PROTEIN EXTRACTABILITY AND RNA:DNA

\begin{tabular}{|c|c|c|c|}
\hline Source & No. & Non-exercise & Exerciseb \\
\hline Myofibrillar I mg/g & 23 & $41.47 * \pm 1.87$ & $35.54 * \pm 1.78$ \\
\hline Myofibrillar IIa & 23 & $47.81 * \pm 1.51$ & $44.59 * * \pm 1.44$ \\
\hline Sarcoplasmic I & 23 & $57.82 * \pm 2.48$ & $55.09 * * \pm 2.37$ \\
\hline Sarcoplasmic IIa & 23 & $86.17 * * \pm 1.98$ & $81.74 * * \pm 1.89$ \\
\hline NPN I & 23 & $6.16 \pm .62$ & $5.35 \pm .59$ \\
\hline NPN II & 23 & \pm .20 & 6.58 \\
\hline RNA-DNA I & 23 & \pm .48 & \pm .46 \\
\hline RNA-DNA IIa & 23 & $4.66 \pm .40$ & \pm .38 \\
\hline
\end{tabular}

asignificant $P<.01$ trial difference.

${ }^{b}$ Sixty-minute treadmill exercise 5 days/week.

** Significant $\mathbf{P}<.01$.

lactate values (Marple et al., 1969). Weiss et al. (1974) reported substantial increases in serum lactate as a result of short term severe exercise. No exercise influence on serum lactate was revealed by the data in table 4 and was probably the result of the conditioned exercise.

Blood cholesterol levels declined from on-test to off-test blood samples (table 4) but were not influenced by exercise. Similarly, liver cholesterol concentrations were not influenced by exercise. The apparent conditioning effect of daily exercise is revealed by the physiological data shown in table 4.

The possibility that induced exercise may influence muscle protein composition was evaluated. In table 5 are presented gracilus RNA-DNA and protein extractability data. In earlier studies Moser (1972) and Moser et al. (1972) did not observe significant differences in RNA-DNA among genetic lines of swine, sex

TABLE 6. LEAST SQUARES MEANS AND STANDARDERRORS FOR PERCENT LEAN, FAT AND BONE OF HAM CROSS SECTIONS

\begin{tabular}{|c|c|c|c|c|}
\hline Source & No. & Non-exercise & Exercisec & $\begin{array}{c}\text { Coefficient } \\
\text { of } \\
\text { variation }\end{array}$ \\
\hline Rt. butt portion lean $\mathrm{b} \%$ & 56 & $79.14 \pm .87$ & $79.47 \pm .84$ & 6.01 \\
\hline Rt. butt portion fata \% & 56 & $18.24 \pm .83$ & $17.18 \pm .80$ & 27.17 \\
\hline Rt. butt portion bonea $\%$ & 56 & $2.82 \pm .25$ & $3.36 \pm .24$ & 46.84 \\
\hline Lt. butt portion leana $\%$ & 56 & $78.29 \pm .69$ & $79.17 \pm .66$ & 7.60 \\
\hline Lt. butt portion fat ${ }^{\mathrm{a}} \%$ & 56 & $18.21 \pm .64$ & $17.14 \pm .62$ & 31.61 \\
\hline Lt. butt portion bonea $\%$ & 56 & $3.51 \pm .24$ & $3.70 \pm .23$ & 55.13 \\
\hline Rt. center portion leana $\%$ & 56 & $74.84 \pm 1.06$ & $74.45 \pm 1.02$ & 8.78 \\
\hline Rt. center portion fata $\%$ & 56 & $22.31 \pm 1.02$ & $22.85 \pm .98$ & 27.24 \\
\hline Rt. center portion bonea $\%$ & 56 & $2.84 \pm .18$ & $2.70 \pm .18$ & 52.74 \\
\hline Lt. center portion leana \% & 56 & $74.42 \pm 1.19$ & $76.21 \pm 1.15$ & 11.28 \\
\hline Lt. center portion fata $\%$ & 56 & $22.85 \pm 1.19$ & $21.20 \pm 1.15$ & 38.14 \\
\hline Lt. center portion bonea $\%$ & 56 & $2.73 \pm .18$ & $2.60 \pm .18$ & 50.43 \\
\hline Rt. shank portion leana \% & 56 & $50.24 \pm 1.30$ & $53.22 \pm 1.25$ & 19.06 \\
\hline Rt. shank portion fata $\%$ & 56 & $37.51 \pm 1.27$ & $34.18 \pm 1.22$ & 30.67 \\
\hline Rt. shank portion bonea $\%$ & 56 & $12.26 \pm .57$ & $12.56 \pm .55$ & 26.52 \\
\hline Lt. shank portion leana $\%$ & 56 & $50.41 \pm$ & $53.76 \pm 1.38$ & 22.13 \\
\hline Lt. shank portion fata $\%$ & 56 & $34.43 \pm$ & $36.10 \pm 1.41$ & 35.34 \\
\hline Lt. shank portion bone ${ }^{a} \%$ & 56 & $13.53 \pm .41$ & $13.54 \pm .59$ & 21.71 \\
\hline
\end{tabular}

\footnotetext{
asignificant $\mathbf{P}<.01$ trial difference.

${ }^{b}$ Significant $P<.05$ trial difference.

c 60 min. treadmill exercise 5 days/week.
} 
and different dietary levels of protein. Data in table 5 indicate no major differences due to exercise or sampling time.

Weiss et al (1971) reported that concentrations of sarcoplasmic and myofibrillar protein increased significantly $(\mathrm{P}<.01)$ in a swine growth and development study. A significant $(\mathrm{P}<.01)$ increase in myofibrillar and sacroplasmic protein is shown for both non-exercised and exercised swine between on-test and off-test determinations. No significant $(\mathrm{P}<.05)$ influence of treadmill exercise was observed for the protein extractability values (table 5 ).

In table 6 are presented percent lean, fat and bone of ham cross sections. Exercise had no significant influence on these traits. The coefficients of variation, particularly for the fat and bone components, and the significant trial differences would suggest that considerable variability exists in this form of measurement.

\section{Literature Cited}

A.M.S.A. 1967. Recommended Guides for Carcass Evaluation and Contests. Amer. Meat Sci. Ass. Chicago, 111 .

Annonymous. 1963. Pork quality standards. Wisc. Agr. Exp. Sta. Spec. Bull. 9.

A.O.A.C. 1965. Official Methods of Analysis (10th Ed.) Association Official Agricultural Chemists. Washington, D.C.

Harvey, W. R. 1960. Least Squares Analysis of Data with Unequal Subclass Numbers. U.S.D.A. Pub. ARS-20-8.

Helendar, E. 1957. On quantitative muscle protein determination. Sarcoplasmic and myofibril protein content of normal and atrophic skeletal muscles. Acta Phys. Scand 41:1.

Lawrie, R. A. 1961. Studies in the muscle of meat animals. I. Differences in composition of beef longissimus dorsi muscles determined by age and anatomical location. J. Agr. Sci. 56:249.

Mandigo, R. W., E. R. Peo, Jr., R. C. Kumm and B. D. Moser. 1971. Influence of exercise on pork carcass composition. J. Anim. Sci. 33:220 (Abstr.).

Marbach, E. P. and M. H. Weil. 1967. Rapid enzymatic measurement of blood lactate and pyruvate. Clin. Chem. 13:314.

Marple, D. N., D. G. Topel and C. Y. Matsushima. 1969. Influence of induced adrenal insufficiency and stress on porcine plasma and muscle characteristics. J. Anim. Sci. 29:882.

Moser, B. D. 1972. The effect of genetic line, sex and source and level of protein on muscle RNA-DNA in the pig. Ph.D. Thesis. Univ. Nebr.-Lincoln Library, Lincoln.

Moser, B. D., E. R. Peo, Jr., D. R. Zimmerman and P.
J. Cunningham. 1972. A biopsy technique for sampling the gracilus muscle in the baby pig. $J$. Anim. Sci. 34:752.

Pearson, S., S. Stern and T. H. McGavack. 1953. A rapid, accurate method for determination of total cholesterol in serum. Anal. Chem. 25:813.

Peo, E. R., R. W. Mandigo, G. F. Wehrbein, P. J. Cunningham and P. E. Vipperman, Jr. 1970. Effect of treadmill exercise on body traits of G-F swine. J. Anim. Sci. 31:175 (Abstr.).

Raabo, E. and T. C. Terkildsen. 1960. On the enzymatic determination of blood glucose. Scand. J. Clin, and Lab. Invest. 12:402.

Schneider, W. C. 1945. Phosphorus compounds in animal tissues. 1. Extraction and estimation of desoxy pentose nucleic acid and of pentose nucleic acid. J. Biol. Chem. 161:293.

Steel, R. G. D. and J. H. Torrie. 1960. Principles and Procedures of Statistics. McGraw-Hill Book Co. New York.

Stromer, M. H., D. E. Goll and J. H. Roberts. 1966. Cholesterol in subcutaneous and intramuscular lipid depots from bovine carcasses of different maturity and fatness. J. Anim. Sci. 25:1145.

Svajgr, A. J., L. E. Lucas, R. W. Mandigo and E. R. Peo, Jr. 1968. Effect of floor structure in confinement and drylot space allotment on growth, carcass and bone development in G-F swine. J. Anim. Sci. 27:1136 (Abstr.).

Svajgr, A. J., E. R. Peo, Jr. and P. E. Vipperman, Jr. 1969. Effects of dietary levels on manganese and magnesium on performance of growing-finishing swine raised in confinement and on pasture. $J$. Anim. Sci. 29:439.

Topel, D. G. and R. A. Merkel. 1967. Effect of exogenous prednisolone and methyl prednisolone upon plasma 17-hydroxycorticosteriod levels and some porcine muscle characteristics. J. Anim. Sci. 25:277.

Topel, D. G. 1966. Adapted procedure for myoglobin determination in pork muscle as cited in Kunert, G. F. 1971. The Effect of Hormone Combination and Dietary Protein Levels on Some Carcass Characteristics of Two Genetic Lines of Swine. M.S. Thesis, Univ. Nebr .-Lincoln.

U.S.D.A. 1969. Pork carcasses U.S. Grades. USDA Consumer and Marketing Service Livestock Division. Washington, D.C. Jan. 1969. 0-328-549.

Weiss, G. M., D. G. Topel and R. C. Ewan. 1971. Growth comparison of a muscular and fat strain of swine. I. Relationship between muscle quality and quantity, plasma lactate and 17-hydroxycorticosteriod. J. Anim. Sci. 32:1119.

Weiss, G. M., D. G. Topel, D. G. Siers and R. C. Ewan. 1974. Influence of adrenergic blockade upon some endocrine and metabolic parameters in a stresssusceptible and a fat strain of swine. J. Anim. Sci. 38:591.

Wierbicki, E., L. E. Kunkle and F. E. Deatherage. 1957. Changes in the water-holding capacity and cationic shifts during the heating and freezing and thawing of meat as revealed by a simple centrifugal method for measuring shrinkage. Food Tech. 11:69. 